\title{
Best Practices in the M-Learning Design
}

\section{Amalan Terbaik dalam Rekabentuk Aplikasi M-Pembelajaran}

\author{
Marlina Mohamad $^{1 *}$ \\ ${ }^{1}$ Universiti Tun Hussein Onn Malaysia, Parit Raja, Batu Pahat, 86400, MALAYSIA \\ *Corresponding Author
}

DOI: https://doi.org/10.30880/ojtp.2021.06.01.005

Received 16 January 2021; Accepted 16 March 2021; Available online 31 March 2021

\begin{abstract}
E-learning applications or online learning is a very broad topic. This article discusses best practices in designing online learning to provide the best learning experience to students. Recently too many e-learning applications have been produced to help the learning process to be easily accessible anytime and anywhere. Students are so excited because access to learning materials is no longer limited to printed materials. The results of studies on the effectiveness of online learning show inconsistent findings. This is because most of the applications developed do not emphasize effective design. If applications are developed without considering the design principles of an effective e-learning application, it is impossible to provide a meaningful learning experience to students. So, these best practices have been gathered through analytical documents from books, journal articles and successful e-learning developers to help designers and developers of e-learning applications to produce effective applications. There are three main things that need to be emphasized in the design of e-learning applications, namely interface design, content design and interaction design. In interface design, among the things that are evaluated is how to produce an interface that can use the cognitive load effectively. Meanwhile, for content design, what is the appropriate learning and teaching theory to be applied so that the learning experience becomes something meaningful. For interaction design, it is important for the behavior of an application to be predictable and usable. Good interaction design shows features such as easy to use, efficient, safe, easy to learn and easy to remember how to use it. In this article, best practices for designing according to these three aspects will be discussed. Although these best practices are still not comprehensive, they can help learning application developers, teachers, instructors, lecturers, or trainers to be able to provide online learning materials and design e-learning interesting applications effectively.
\end{abstract}

Keywords: e-learning, mobile learning, interface design, human-computer interaction, user experience 


\begin{abstract}
Abstrak: Aplikasi e-pembelajaran atau pembelajaran dalam talian adalah topik yang sangat luas. Artikel ini membincangkan amalan terbaik dalam merekabentuk pembelajaran secara atas talian supaya dapat memberikan pengalaman pembelajaran terbaik kepada pelajar. Kebelakangan ini terlalu banyak aplikasi e-pembelajaran dihasilkan bagi membantu proses pembelajaran supaya mudah dicapai pada bila-bila masa dan di mana-mana sahaja. Pelajar begitu teruja kerana akses kepada bahan pembelajaran tidak lagi terhad kepada bahan bercetak. Hasil kajian mengenai keberkesanan pembelajaran atas talian menunjukkan dapatan yang tidak selari. Ini disebabkan oleh kebanyakan aplikasi yang dibangunkan tidak menitik beratkan rekabentuk yang berkesan. Jika aplikasi dibangunkan tanpa mengikut ciri-ciri rekabentuk aplikasi e-pembelajaran yang berkesan, adalah mustahil untuk memberikan pengalaman pembelajaran yang bermakna kepada pelajar. Jadi amalan terbaik ini telah dikumpulkan melalui dokumen analisis dari buku dan artikel jurnal bagi membantu perekabentuk dan pembangun aplikasi e-pembelajaran untuk menghasilkan aplikasi yang berkesan. Terdapat tiga perkara utama yang perlu dititikberatkan dalam rekabentuk aplikasi e-pembelajaran iaitu rekabentuk antaramuka, rekabentuk isi kandungan dan rekabentuk interaksi. Dalam rekabentuk antaramuka, antara perkara yang dinilai ialah bagaimana cara menghasilkan antaramuka yang dapat menggunakan beban kognitif (cognitive load) dengan berkesan. Manakala, bagi rekabentuk isi kandungan, apakah teori pembelajaran dan pengajaran yang sesuai diaplikasikan supaya pengalaman pembelajaran menjadi sesuatu yang bermakna. Bagi rekabentuk interaksi pula, penting untuk tingkahlaku sesebuah aplikasi dapat diramal, dijangkakan, dan boleh digunakan. Rekabentuk interaksi yang baik menunjukkan ciri-ciri-ciri seperti mudah digunakan, cekap, selamat, mudah dipelajari dan mudah diingat bagaimana menggunakannya. Dalam artikel ini, amalan terbaik untuk merekabentuk mengikut tiga aspek ini akan dibincangkan. Walaupun amalan terbaik ini masih tidak menyeluruh, namun ia dapat membantu pembangun aplikasi pembelajaran, guru, pengajar, pensyarah atau jurulatih supaya dapat menyediakan bahan pembelajaran secara atas talian dan rekabentuk aplikasi e-pembelajaran dengan berkesan dan menarik.
\end{abstract}

Katakunci: aplikasi e-pembelajaran, mobile learning, rekabentuk antaramuka aplikasi, pengalaman pengguna

\title{
1. Pengenalan
}

Kewujudan aplikasi mudah alih telah membawa perubahan besar secara positif dalam semua bidang seperti bidang penjagaan kesihatan, peruncitan, perkilangan, sukan, kejuruteraan dan pendidikan. Hampir tiada bidang yang tidak terjejas dengan kewujudan aplikasi mudah alih. Bermula dari pembelajaran elektronik atau e-pembelajaran sehinggalah ke pembelajaran mudah alih atau m-pembelajaran, teknologi telah merubah sepenuhnya landskap industri pendidikan. Dalam artikel ini aplikasi m-pembelajaran merujuk kepada aplikasi mudah alih untuk tujuan pembelajaran, iaitu program komputer atau aplikasi perisian yang dibangunkan dan dipasang pada peranti mudah alih seperti telefon, tablet, atau peranti mudah alih yang lain bertujuan untuk mempelajari sesuatu kursus atau cabang ilmu.

Aplikasi pembelajaran mudah alih atau m-pembelajaran (selepas ini dipanggil aplikasi m-pembelajaran) menyediakan kecekapan yang tinggi dan menyeronokkan dalam pembelajaran atau pengajaran di dalam atau luar kelas. Ia memberikan banyak kebaikan kepada pelajar dan institusi pendidikan. Terdapat beberapa kelebihan aplikasi mpembelajaran iaitu yang pertama, pembelajaran tanpa had (Gautam,2018). Pelajar mempunyai akses kepada sumber dan pengetahuan yang tiada batasan dan maklumat tidak terhad kepada buku sahaja. Kedua, kos untuk mendapatkan ilmu pengetahuan menjadi lebih rendah kerana banyak kursus yang boleh dipelajari tanpa perlu berdaftar atau menyertai mana-mana pusat latihan atau institut pendidikan. Oleh itu, pelajar boleh belajar banyak perkara tanpa membayar sebarang yuran pengajian. Ketiga, permintaan yang tinggi dari pelajar terhadap aplikasi pendidikan kerana menepati cara pembelajaran masa kini. Pertumbuhan pasaran aplikasi pembelajaran datang dari segmen pendidikan tinggi. Institusi pendidikan tinggi semakin banyak menggunakan aplikasi pembelajaran/pendidikan untuk penilaian, pengedaran kandungan pendidikan, perkongsian jadual, dan aktiviti lain. Ramai pelajar mula menunjukkan minat untuk memuat turun dan menggunakan aplikasi yang disertakan dengan analisis pembelajaran kerana aplikasi ini memainkan peranan penting dalam memberikan maklumat yang disokong data yang dapat memperlihatkan keseluruhan aktiviti pembelajaran. Hasilnya, pertumbuhan bahagian pasaran aplikasi pendidikan oleh segmen pendidikan tinggi sangat ketara.

Walaubagaimanapun, terdapat juga beberapa cabaran utama dalam menggunakan aplikasi m-pembelajaran yang menganggu penguasaan ilmu pengetahuan dan menyukarkan penyelesaian tugasan. Antara cabarannya ialah saiz skrin yang lebih kecil, gangguan dari persekitaran, kehilangan sambungan internet dan penggunaan beban kognitif yang tinggi (Badiu, 2015). Saiz skrin yang kecil menghadkan jumlah kandungan yang boleh dilihat pada satu-satu masa. Jadi, pelajar akan menggunakan lebih ruang ingatan untuk mengingat maklumat yang baru sahaja dilihat. Kajian menunjukkan keadaan ini menjadi lebih sukar apabila ia melibatkan subjek atau kursus yang lebih kompleks seperti matematik. Oleh kerana beban kognitif yang lebih tinggi telah digunakan untuk memastikan pembelajaran menggunakan peranti mudah alih, maka beban kognitif yang tinggal untuk memahami subjek atau kursus menjadi berkurangan. Walaupun cabarancabaran ini tidak boleh dihapuskan sama sekali namun ia boleh diatasi.

Oleh yang demikian, bagi memastikan aplikasi m-pembelajaran memberikan kesan pembelajaran yang bermakna, menarik dan berkesan, aspek rekabentuk adalah sangat penting dan perlu diberi perhatian. Rekabentuk yang perlu 
ditekankan ialah rekabentuk antaramuka, rekabentuk isi kandungan dan rekabentuk interaksi. Namun dalam artikel ini, hanya amalan baik untuk rekabentuk antaramuka sahaja yang akan dibincangkan.

\section{Metodologi}

Melaksanakan penyelidikan saintifik untuk rekabentuk antaramuka dan pengalaman pengguna (UX) sukar untuk dilaksanakan. Penyelidikan saintifik perlu dilakukan dalam persekitaran saintifik bersama sekumpulan orang yang ditentukan, dan penyelidikan tersebut perlu diulang untuk memastikan hasilnya tepat dan konsisten. Walaubagaimanapun, penyelidikan dalam rekabentuk antaramuka dan pengalaman pengguna adalah lebih fleksibel dan mempunyai tujuan yang berbeza daripada penyelidikan ilmiah. Tambahan pula, terdapat banyak pembolehubah luaran yang sukar untuk dikawal. Antara ancaman luaran (external threat) terhadap sesuatu faktor yang akan mempengaruhi hasil penyelidikan ialah masa, tempat dan situasi sosial semasa menggunakan sesuatu aplikasi.

Oleh yang demikian, artikel ini dihasilkan melalui analisis dokumen dari laman web, buku, dan artikel jurnal bagi mengenalpasti amalan terbaik dalam rekabentuk aplikasi pembelajaran mudah alih. Antara laman web yang dirujuk ialah https://www.nngroup.com/. Nielsen Norman Group (NNG) merupakan sebuah syarikat penyelidikan dan perundingan pengalaman pengguna atau User Experience (UX) yang dipercayai oleh organisasi terkemuka di seluruh dunia untuk memberikan panduan yang boleh dipercayai mengenai UX. Pengasas NNG ialah Jacob Nielsen (penulis "10 usability heuristic") dan Donald A. Norman (merupakan penulis buku "The Design of Everyday Things") diiktiraf di seluruh dunia kerana kepimpinan dan kepakaran mereka dalam menentukan UX.

Selain itu, analisis dokumen juga dibuat terhadap laman web https://www.interaction-design.org/. Interaction Design Foundation ini merupakan satu badan yang diketuai oleh pakar-pakar ternama dalam bidang ini seperti Donald A. Norman, Daniel Rosenberg dan Jonas Löwgren. Bagi analisis dokumen seperti buku dan jurnal, senarai rujukan disertakan dalam penulisan dapatan dalam artikel ini.

\section{Data Analisis}

Jadual 1 menunjukkan hasil dokumen analisis dari website, buku dan jurnal artikel. Tanda X dalam jadual 1 menunjukkan elemen tersebut disebut dalam dokumen sebagai strategi atau amalan baik dalam merekabentuk antaramuka aplikasi terutamanya aplikasi m-pembelajaran.

\section{Jadual 1 - Elemen rekabentuk antaramuka aplikasi m-pembelajaran}

\begin{tabular}{|c|c|c|c|c|c|c|c|}
\hline $\begin{array}{l}\text { Elemen } \\
\text { /dokumen }\end{array}$ & $\begin{array}{l}\text { Meminimum- } \\
\text { kan beban } \\
\text { kognitif }\end{array}$ & $\begin{array}{l}\text { Kurangkan } \\
\text { berselera- } \\
\text { kan }\end{array}$ & $\begin{array}{l}\text { Kurang- } \\
\text { kan tugas }\end{array}$ & $\begin{array}{l}\text { Membahagi- } \\
\text { kan tugas }\end{array}$ & $\begin{array}{l}\text { Screen } \\
\text { familiarity }\end{array}$ & $\begin{array}{l}\text { Meminimum- } \\
\text { kan input } \\
\text { pengguna }\end{array}$ & Konsisten \\
\hline $\begin{array}{l}\text { Nielsen } \\
\text { Norman } \\
\text { Group } \\
\text { (web) } \\
\end{array}$ & 0 & $X$ & $\mathrm{X}$ & $\mathrm{X}$ & $X$ & $\infty$ & $X$ \\
\hline $\begin{array}{l}\text { Interaction } \\
\text { Design } \\
\text { Foundation } \\
\text { (web) }\end{array}$ & $X$ & $X$ & $\mathrm{X}$ & $X$ & $X$ & $X$ & $X$ \\
\hline $\begin{array}{l}\text { Elearning } \\
\text { industry } \\
\text { (web) }\end{array}$ & $\mathrm{X}$ & $\mathrm{X}$ & $\mathrm{X}$ & & $\mathrm{X}$ & $\mathrm{X}$ & $\mathrm{X}$ \\
\hline $\begin{array}{l}\text { Don't } \\
\text { Make Me } \\
\text { Think } \\
\text { (buku) }\end{array}$ & $\mathrm{X}$ & & & $\mathrm{X}$ & $\mathrm{X}$ & $\mathrm{X}$ & $\mathrm{X}$ \\
\hline
\end{tabular}

\section{Dapatan Amalan Terbaik Rekabentuk Antaramuka Aplikasi}

Perbezaan antara aplikasi yang berkualiti dan kurang berkualiti adalah berdasarkan kualiti pengalaman pengguna atau user experience (UX). Pengguna mengharapkan sesuatu aplikasi yang digunakan menyediakan semua perkhidmatan, masa memuat naik dan turun yang cepat, kemudahan semasa penggunaan dan keseronokan semasa interaksi. Jika sesuatu aplikasi tersebut ingin berjaya dan menarik perhatian pengguna, UX perlu diambilkira bukan hanya sebagai sebahagian dari aspek reka bentuk yang kecil, tetapi komponen penting dalam strategi pembangunan produk atau aplikasi. Hasil analisis terhadap dokumen dan juga web site, antara amalan baik yang boleh diterapkan dalam rekabentuk antaramuka m-pembelajaran adalah meminimumkan beban kognitif, kurangkan berselerakan, kurangkan tugas, membahagikan tugas 
kepada saiz yang lebih kecil, gunakan skrin biasa bagi pengguna, meminimumkan input dari pengguna dan konsisten (Sharp, Preece \& Rogers, 2019).

\subsection{Meminimumkan Beban Kognitif}

Istilah "beban kognitif" pada mulanya diciptakan oleh ahli psikologi untuk menggambarkan usaha mental yang diperlukan untuk mempelajari maklumat baru (Whitenton, 2013). Beban kognitif merujuk kepada jumlah penggunaan otak atau minda yang diperlukan untuk menggunakan aplikasi. Otak manusia mempunyai kuasa pemprosesan yang terhad, dan apabila aplikasi menyediakan terlalu banyak maklumat sekaligus, ia mungkin dapat membebankan otak dan membuat pengguna cepat berputus asa dan berhenti dari menggunakan aplikasi tersebut. Antara amalan yang baik bagi meminimumkan beban kognitif ialah jadikan arahan mudah. Reka bentuk yang baik adalah jelas atau dipanggil kemampuan (affordances), iaitu kemampuan antaramuka untuk berkomunikasi secara langsung apa tindakan yang boleh dilakukan terhadap antaramuka. Contohnya dalam rekabentuk produk, bentuk kerusi menunjukkan bahawa pengguna boleh duduk di atasnya dan roda tetikus komputer menunjukkan pengguna boleh memutarnya dengan jari. Rajah 1 menunjukkan contoh rekabentuk butang yang mempunyai ciri affordances. Pengguna tidak perlu berfikir panjang untuk memahami fungsinya dan mampu menghalang pengguna dari melakukan kesilapan.

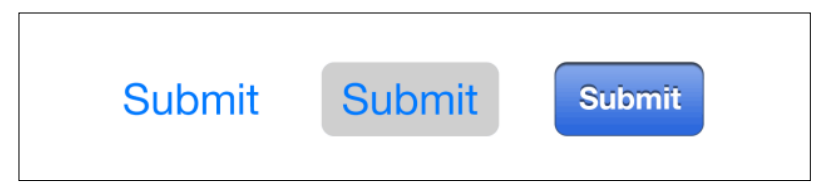

Rajah 1 - Contoh rekabentuk affordances (paling kanan)

Selain itu, untuk meminimumkan beban kognitif rekabentuk antaramuka aplikasi perlulah boleh diramal. Maksudnya, antaramuka harus berkelakuan seperti yang diharapkan pengguna. Keadaan dimana tidak berlaku cognitive friction dan tidak menggunakan beban kognitif pengguna untuk memproses maklumat dan menangani apa yang berlaku di skrin. Contohnya meletakkan animasi dan kejutan pada setiap klik, Nampak kreatif tapi ia bukan idea yang baik untuk aplikasi yang berprestasi baik. Cognitive friction berlaku apabila pengguna berhadapan dengan antaramuka yang nampak intuitif tetapi memberikan hasil yang tidak dijangka. Ketidaksepadanan antara hasil tindakan dan hasil yang diharapkan menyebabkan kekecewaan pengguna dan akan menjejaskan pengalaman pengguna seterusnya meninggalkan aplikasi. Contoh yang baik ialah aplikasi YouTube, sebuah aplikasi yang sangat sederhana dan berjaya digunakan setiap hari oleh semua peringkat umur pengguna, dari pengguna profesional hingga bayi yang menonton kartun.

\subsection{Decluttering (Kurangkan Berselerakan)}

Cluttering atau antaramuka yang penuh boleh menyebabkan pengguna dihujani dengan maklumat yang banyak sekaligus. Clutter adalah musuh utama untuk rekabentuk yang baik. Setiap tambahan butang, imej atau ikon akan menjadikan antaramuka lebih rumit. Memenuhkan antaramuka telah memberikan kesan yang buruk pada antaramuka desktop, apatah lagi jika ia berlaku pada antaramuka telefon mudah alih yang mempunyai saiz skrin yang kecil (limited screen real estate). Membuang semua yang tidak perlu dalam antaramuka aplikasi adalah sangat penting kerana mengurangkan keselerakan akan meningkatkan kefahaman terhadap aplikasi, contohnya seperti dalam Rajah 2 dan Rajah 3. Terdapat teknik-teknik yang boleh dilakukan untuk menghadapi rekabentuk yang clutter. Antaranya memastikan kandungan aplikasi minimum (persembahkan pengguna dengan hanya apa yang mereka perlu tahu). Selain itu, pastikan elemen antaramuka minimum, reka bentuk yang mudah akan menjadikan pengguna selesa dengan produk tersebut. Gunakan teknik pendedahan progresif (progressive disclosure) untuk menunjukkan lebih banyak pilihan (antaramuka memberikan/mendedahkan lebih banyak pilihan selepas interaksi berlaku). 


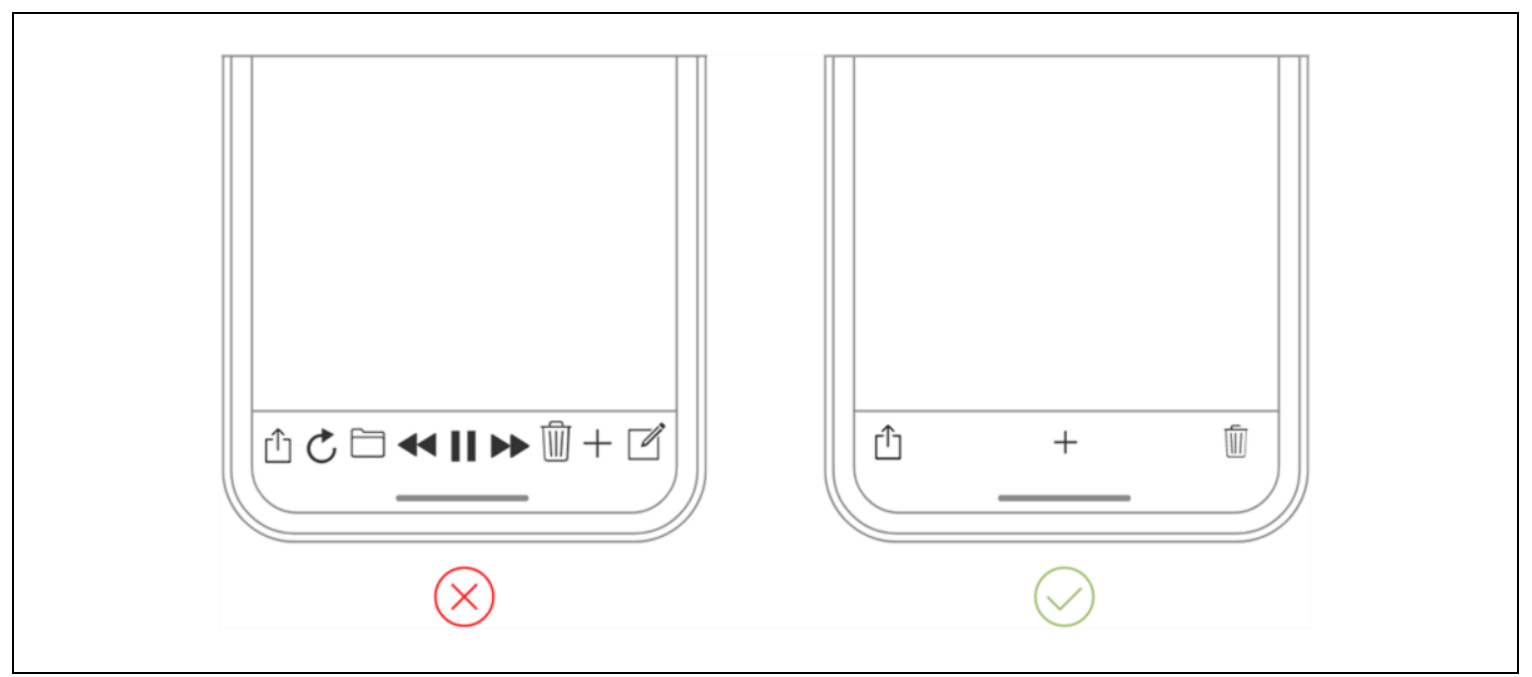

Rajah 2 - Tab bar yang jelas (kanan) jauh lebih baik dari tab bar yang dipenuhi oleh pelbagai ikon (kiri)

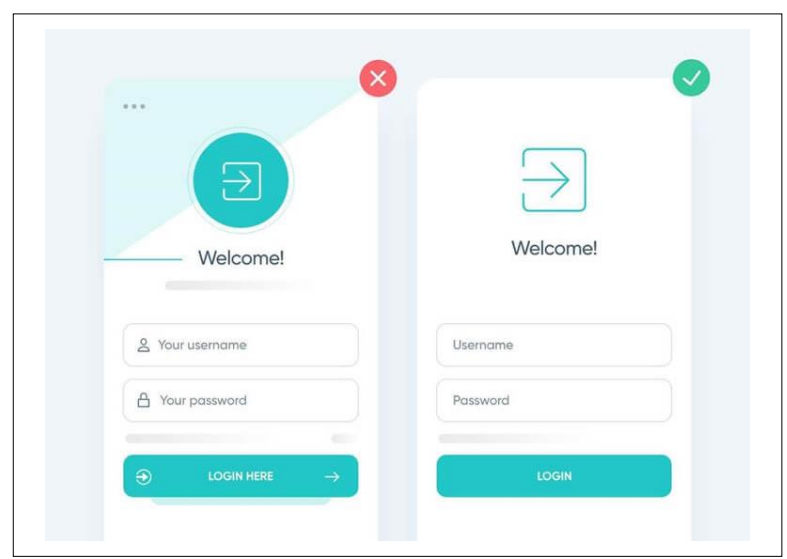

Rajah 3 - Contoh antaramuka yang lebih baik (kanan), buang elemen dan perhiasan yang tidak perlu (sumber: https://uifreebies.net/)

\subsection{Kurangkan Tugas (Offload Task)}

Cari alternatif kepada apa-apa dalam reka bentuk yang memerlukan usaha pengguna (contohnya seperti memasukkan data, membuat keputusan). Contohnya, dalam sesetengah kes, penggunaan semula data yang dimasukkan sebelum ini adalah lebih baik dari meminta pengguna menaip semula maklumat yang sama berulang kali, atau menggunakan maklumat yang ada untuk menetapkan data lalai pintar (smart default). Sekiranya tugas yang ingin disempurnakan memerlukan empat langkah dapat diselesaikan dengan mudah dalam dua langkah sahaja, maka rekabentuk perlu diubah untuk aliran tugas yang lebih pendek. Antara strategi terkini yang digunakan untuk kurangkan tugas ialah anticipatory design.

\subsection{Membahagikan Tugas Kepada Saiz yang Lebih Kecil (Break Tasks Into Bite-Sized Chunks)}

Sekiranya sesuatu tugas mengandungi banyak langkah dan tindakan yang diperlukan dari pengguna, adalah lebih baik membahagikan tugas-tugas tersebut kepada saiz yang lebih kecil. Prinsip ini sangat penting dalam rekabentuk aplikasi supaya ia tidak memberi banyak kerumitan kepada pengguna pada satu-satu masa. Salah satu contoh yang baik ialah aliran keluar (checkout) langkah demi langkah dalam aplikasi e-dagang, di mana pereka bentuk memecah tugas aliran keluar yang kompleks ke dalam proses yang lebih kecil yang memerlukan tindakan pengguna.

\subsection{Gunakan Skrin Biasa Bagi Pengguna (Familiar Screen)}

Skrin biasa adalah skrin yang biasa dilihat pengguna dalam banyak aplikasi. Skrin seperti "Gettings started," "What's new" dan "Search results" telah menjadi standard rasmi untuk aplikasi mudah alih. Ia tidak memerlukan penjelasan tambahan kerana pengguna sudah biasa dengan fungsi skrin tersebut. Ini membolehkan pengguna menggunakan pengalaman sebelumnya untuk berinteraksi dengan aplikasi tanpa perlu mengambil masa yang lama atau menggunakan beban kognitif yang minimum. Menggunakan ikon atau butang yang standard dan sering digunakan oleh kebanyakan aplikasi. Contohnya, biarkan butang 'Home' kelihatan seperti rumah kecil, butang 'Back' - seperti anak panah yang 
menunjuk ke belakang. Gunakan teks yang boleh dijelaskan sendiri (self-explanatory text) dan bukannya simbol kreatif tetapi tidak dikenali.

Butang "Home" adalah jalan keluar kecemasan utama bagi pengguna. Sekiranya pengguna benar-benar tersesat, butang "Back" pun tidak membantu. Jadi, sediakan pengguna satu klik untuk membawa mereka pulang. Pastikan ia jelas dan segera. Butang "Back" juga penting supaya pengguna dapat kembali semula ke tempat asal sebelum sesat. Jadi, jika pengguna melakukan kesilapan ia bukanlah satu pengalaman yang mengerikan jika butang "Back" disediakan (Krug, 2009).

\subsection{Minimumkan Input Dari Pengguna}

Menaip pada skrin kecil adalah mencabar bagi kebanyakan pengguna. Malah pengguna cenderung untuk melakukan kesilapan. Keperluan input pengguna yang paling biasa ialah mengisi borang. Berikut adalah beberapa cadangan praktikal untuk memudahkan proses tersebut. Antaranya memendekkan borang semaksimum mungkin dengan mengeluarkan sebarang medan yang tidak perlu. Aplikasi hanya perlu meminta maklumat minimum dari pengguna seperti dalam Rajah 4.

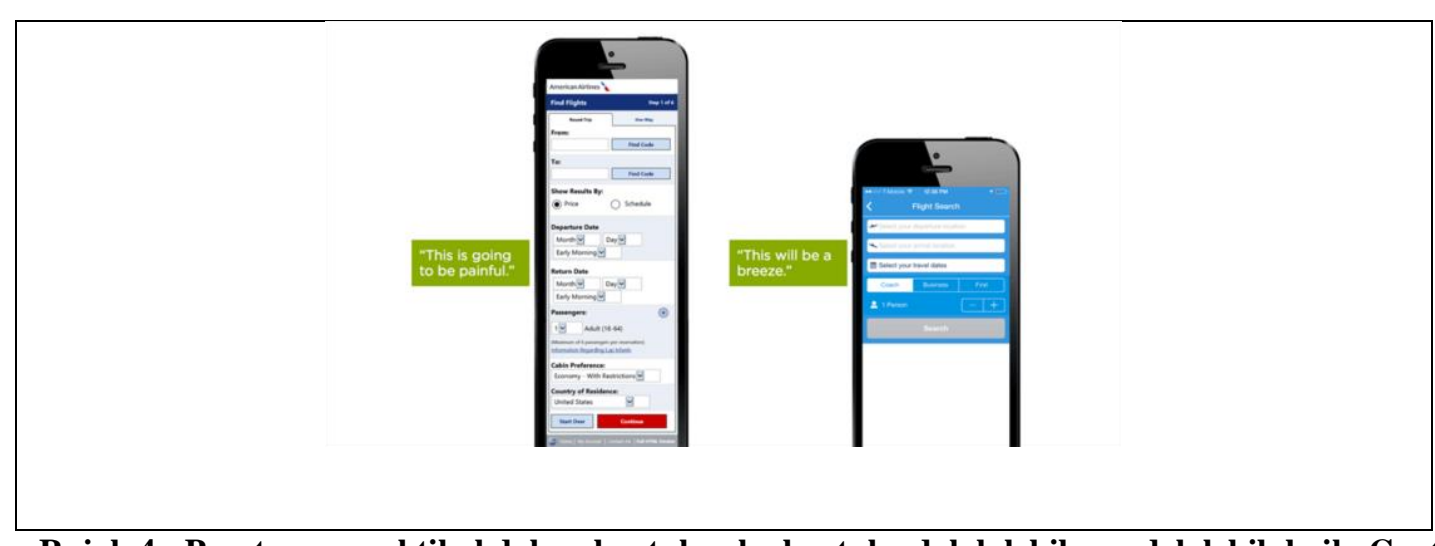

Rajah 4 - Peraturan praktikal dalam bentuk reka bentuk adalah lebih pendek lebih baik. Contohnya menggabungkan pelbagai medan ke dalam satu medan yang mudah diisi (sumber: Luke W.)

Kedua ialah menyediakan input masks. Input masks bermaksud medan akan memberi klu atau gambaran input yang diperlukan oleh medan tersebut. Jadi, pengguna hanya perlu fokus kepada input apa yang perlu dimasukkan, tidak dibebankan dengan perkara yang tidak berkenaan, dapat mempercepatkan proses mengisi borang dan dapat mengesan kesalahan semasa memasukkan input dengan mudah. Selain itu, buat butang dan sasaran dengan saiz yang besar dan bersesuaian supaya mudah ditekan oleh saiz jari yang pelbagai. Akhir sekali, rekabentuk harus dirancang untuk meminimumkan keperluan untuk menaip. Sebagai contoh, daripada meminta pengguna menaip jawapan, lebih baik menyediakan aplikasi dengan hanya perlu memilih dari pilihan yang disediakan. Pastikan pilihan yang diberi cukup besar supaya pengguna dapat memilih pilihan yang diinginkan tanpa mengklik pilihan lain secara tidak sengaja. Elakkan menggunakan tanda bintang (*) untuk maksud optional. Pengguna akan keliru dengan tanda (*) kerana ia sering digunakan untuk menunjukkan medan yang wajib diisi. Rajah 5 menunjukkan panduan bagaimana merekabentuk borang untuk kemasukan input pengguna. Jika semua medan perlu diisi oleh pengguna, maka adalah lebih baik hanya tandakan optional pada medan pilihan.
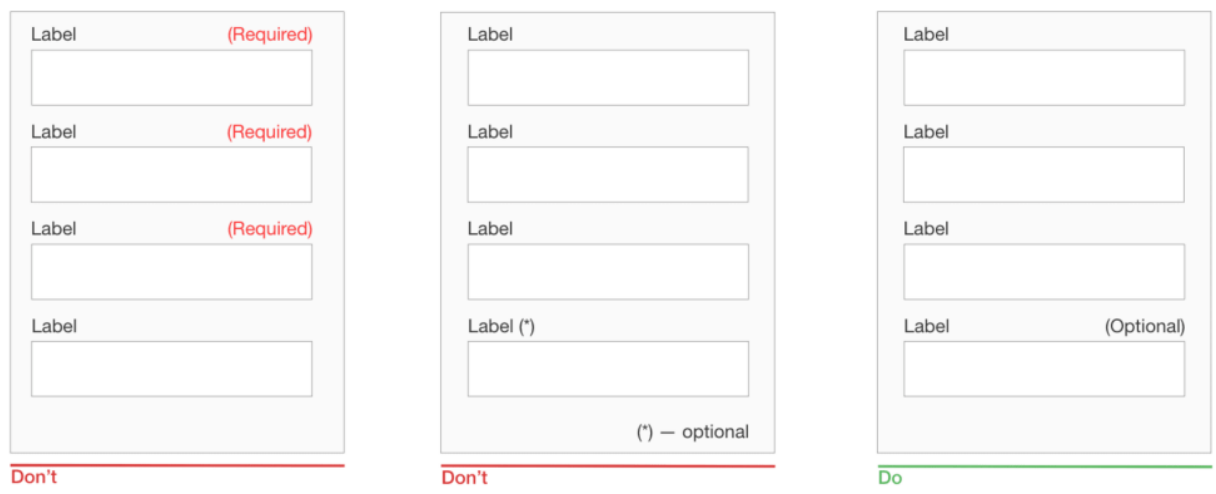

Rajah 5 - Rekabentuk medan jika kebanyakan medan perlu diisi 


\subsection{Konsisten}

Konsisten dalam rekabentuk antaramuka bermaksud memastikan elemen dalam antaramuka pengguna seragam. Elemen rekabentuk mestilah kelihatan dan berkelakuan sama. Ini membantu membuktikan jangkaan pengguna mengenai elemen antaramuka adalah betul. Jadi ia mampu mewujudkan kawalan (sense of control), kebiasaan (familiarity) dan kebolehpercayaan. Platform yang berbeza mempunyai garis panduan rekabentuk antaramuka dan kegunaan yang berbeza dan perlu diberi perhatian semasa fasa perancangan. Sekiranya pembangun merancang antaramuka pengguna untuk platform iOS, perekabentuk perlu membiasakan diri dengan aplikasi iOS dan berusaha untuk mematuhinya. Sekiranya pembangun merancang untuk aplikasi dalam platform Android, perekabentuk perlu mahir dan merasai pengalaman menggunakan aplikasi Android (Wong, 2020).

Konsisten adalah kunci dalam memudahkan pengguna. Prinsip konsisten memastikan rekabentuk dan navigasi tetap dan konsisten. Contoh, sekiranya perekabentuk meletakkan butang "Next" di sudut kanan atas aplikasi, pastikan butang tersebut kekal di tempat yang sama untuk setiap halaman. Contoh seterusnya, sekiranya jawapan yang pengguna terhadap sesuatu soalan betul, akan muncul isyarat hijau, jangan mengubah ke isyarat berwarna lain untuk soalan atau modul pembelajaran seterusnya. Sebilangan besar pengguna bersetuju bahawa ketika mereka ingin membuat carian (search), mereka mencari bar carian di bahagian tengah atas atau kanan aplikasi kerana ini adalah penetapan yang sering digunakan oleh kebanyakan aplikasi. Konsisten membantu mengurangkan masa pembelajaran sesebuah aplikasi kerana pengguna telah membiasakan diri dengan pengalaman yang diberikan. Konsisten adalah penting untuk memberikan pengalaman pengguna yang terbaik.

\section{Kesimpulan}

Amalan baik yang dibincangkan boleh dijadikan sumber rujukan pembangun aplikasi terutamanya aplikasi mpembelajaran. Pandemik Covid-19 telah mengubah lanskap pembelajaran. M-pembelajaran merupakan salah satu teknologi yang boleh diaplikasikan untuk menyokong perubahan yang berlaku. Oleh yang demikian, sudah tiba masanya untuk merekabentuk antaramuka aplikasi m-pembelajaran dengan UX ringkas dan konsisten. Ia sangat membantu pengguna menggunakan aplikasi terutamanya pelajar dalam menggunakan aplikasi e-pembelajaran. Dengan penggunaan strategi rekabentuk antaramuka dan pengalaman pengguna (UX) yang tepat, aplikasi epembelajaran dapat mengubah pembelajaran tradisional yang monotonous menjadi pembelajaran yang menyeronokkan, meningkatkan penglibatan dan perhatian pelajar serta interaktif. Malah muat turun aplikasi juga akan meningkat.

\section{Penghargaan}

Artikel ini ditulis menggunakan sebahagian data yang diperolehi dari kajian ini dibawah pembiayaan Geran K019, Universiti Tun Hussein Onn Malaysia.

\section{Rujukan}

Budiu, R. (2015). Mobile user experience: Limitations and strengths. Nielsen Norman Group

Gautam, P (2018). What The Advantages And Disadvantages Of Mobile Learning Are. ELearning Industry

Krug, S (2009). Don't Make Me Think: A Common Sense Approach to Web Usability. USA: Pearson Education

Sharp, H., Preece, J., \& Rogers, Y. (2019). Interaction Design: Beyond Human-Computer Interaction (5 ${ }^{\text {th }}$ Ed). USA: Wiley

Whitenton, K (2013). Minimize Cognitive Load to Maximize Usability. Nielsen Norman Group

Wong, E (2020). Principle of Consistency and Standards in User Interface Design. Interaction Design Org 